\title{
Pengembangan Multimedia Pembelajaran Teks Deskriptif Bahasa Inggris SMP
}

\author{
Heriyanti Tahang \\ Yuliana \\ Program Studi Pendidikan Bahasa Inggris \\ Universitas Muhammadiyah Sorong \\ heriyantitahang@um-sorong.ac.id
}

\begin{abstract}
A b s tra c t
Nowadays, Technology improves massively in hence learning media used in teaching and learning processes should go along with it. Using interactive learning multimedia becomes one of the efforts to do. Meanwhile based on the interview result with English teachers, iit has not been a trend especially in teaching English monolog text, descriptive text, in Junior High School. Based on that reason, the recent research aimed to develop multimedia called Wikitext in learning English Descriptive Text that is appropriate and effective to use in teaching descriptive text in Junior High School Kota Sorong. Research and Development design was conducted through ADDIE design (Analyse, Design, Develop, Implement \& Evaluate). The place to try the product's effectiveness was SMP Islam GUPPI Kota Sorong. The validity test result has shown that the material and the multimedia has been appropriate with 3.85 average as a result in a very valid category. To know the effectiveness of the product, the multimedia Wikitext has been implemented in teaching descriptive text at class VIII SMP Islam GUPPI using an LCD projector. The Pre-test and post-test results revealed that students got to score 60 rises from $10 \%$ to $44 \%$ in once implementation. It concluded that the use of multimedia Wikitext was effective in teaching the descriptive text.
\end{abstract}

Keyword : Multimedia, Descriptive Text, Wikitext

\begin{abstract}
A bstrak
Perkembangan teknologi saat ini semakin pesat sehingga media pembelajaran yang digunakan dalam proses belajar mengajar harus mengikuti perkembangan tersebut. Menggunakan multimedia pembelajaran interaktif menjadi salah satu upaya yang bisa dilakukan. Namun berdasar pada hasil wawancara guru Bahasa Inggris, penggunaan multimedia masih jarang digunakan dalam pembelajaran teks monolog Bahasa Inggris di SMP. Penelitian ini bertujuan mengembangkan produk multimedia pembelajaran teks monolog Wikitext khususnya teks deskriptif yang layak dan efektif digunakan dalam pembelajaran teks deskriptif di SMP Kota Sorong. Penelitian ini menggunakan desain Research \& Development dengan model pengembangan ADDIE yaitu Analyse, Design, Develop, implement dan Evaluate. Kelas VIII SMP Islam Guppi Kota Sorong menjadi tempat Uji Keefektifan Multimedia ini. Hasil Validasi ahli menunjukkan bahwa multimedia Wikitext telah Valid dengan hasil rata-rata 3.85 dalam kategori sangat valid sehingga produk ini layak digunakan. Untuk mengetahui keefektifan produk, uji coba dilakukan di kelas VIII SMP Islam Guppi menggunakan Multimedia Wikitext dengan LCD Proyektor, perbandingan hasil Pretest dan post-test peserta didik yang memperoleh nilai 60 meningkat dri $10 \%$ menjadi $44 \%$ dengan nilai rata-rata 64.5 dalam satu kali uji coba. Hal ini menunjukkan bahwa Penggunaan Multimedia WikiText efektif digunakan dalam pembelajaran teks deskriptif karena telah berhasil meningkatkan skor perolehan peserta didik.
\end{abstract}

Kata Kunci : Multimedia, Teks Deskriptif, Wikitext

\begin{tabular}{|c|}
\hline Article Info \\
\hline $\begin{array}{l}\text { Naskah Diterima : } \\
\text { 2019-10-31 }\end{array}$ \\
\hline $\begin{array}{l}\text { Naskah Direvisi: } \\
\text { 2019-11-01 }\end{array}$ \\
\hline $\begin{array}{l}\text { Naskah Disetujui: } \\
\text { 2020-02-09 }\end{array}$ \\
\hline
\end{tabular}




\section{A. PENDAHULUAN}

Perkembangan teknologi multimedia saat ini telah menunjukkan potensi luar biasa dalam merubah cara seorang berfikir dan belajar, guna memperoleh, mencari, menyesuaikan informasi dan lainnya. Multimedia tentunya menyediakan kesempatan bagi para pendidik untuk selalu mengevaluasi strategi pembelajaran demi mencapai tujuan pembelajaran secara maksimal. Melalui multimedia, para peserta didik diharapkan akan lebih mudah menentukan bagaimana dan dengan cara apa peserta didik mampu menyerap informasi yang tersedia secara efisien, efektif, dan cepat. Kemampuan yang ditunjukkan oleh multimedia yang terhubung dengan internet akan semakin mempermudah akses dan perolehan informasi yang diharapkan di zaman teknologi digital ini. Sebagaimana Supardi (2014) menyatakan bahwa pemanfaatan teknologi dalam proses belajar mengajar merupakan pembaharuan yang tepat dilakukan pada zaman berteknologi ini.

Sajian kreativitas audio visual yang disebut multimedia mampu mengubah visualisasi jauh lebih menarik. Information and Communication Technologies (ICT), contohnya komputer atau laptop yang didukung oleh perangkat multimedia mampu menampilkan teks non-sekuensial, multidimensial, dan nonlinear secara interaktif. Dengan tampilan seperti itu, multimedia melalui komputer akan mampu mengakomodir perbedaan proses penerimaan pembelajaran peserta didik, khususnya peserta didik yang lamban karena komputer akan sangat sabar dan tidak akan bosan dalam melaksanakan isntruksi yang diinginkan oleh peserta didik.

Multimedia interaktif yang berbasis komputer dalam pembelajaran adalah gabungan antara unsur teknologi yang berupa perangkat lunak dan Pendidikan. Di zaman teknologi ini, multimedia interaktif telah berubah menjadi trend tersendiri yang diminati karena multimedia ini mampu memberikan kemudahan kepada para peserta didik dalam memahami tujuan pembelajaran. Oleh karena itu, setelah kami mengobservasi ke sekolah-sekolah serta melalui wawancara dengan beberapa guru, telah ditemukan beberapa masalah yang kemungkinan besar dapat diatasi dengan penggunaan multimedia pembelajaran interaktif berbasis komputer. Diantaranya, kurangnnya ketertarikan peserta didik dalam mempelajari berbagai jenis teks Bahasa Inggris dan masih jarangnya dilakukan pembelajaran Bahasa Inggris menggunakan multimedia interaktif atau komputer. Padahal sebagai jaman yang sarat akan teknologi, sudah saatnya multimedia ini menjadi trend dalam proses belajar mengajar khususnya dalam pembelajaran Bahasa Inggris.

Di beberapa SMPN/MTsN yang telah diobservasi di Kota Sorong, ditemukan bahwa rata-rata guru Bahasa Inggris merasa perlu meningkatkan kemampuan peserta didik dengan menggunakan teknologi. Mengingat teknologi zaman sekarang ini jauh semakin canggih dari sebelumnya. Para guru juga merasa bahwa peserta didik perlu menyegarkan minat belajar mereka dengan metode pembelajaran yang sesuai perkembangan zaman. Tapi sayangnya, para guru belum mampu menyajikan media pembelajaran yang mempermudah mereka untuk mengajarkan berbagai jenis teks monolog di sekolah.

Sebagai landasan dalam pelaksanaan penelitian ini, peneliti telah merangkum beberapa penelitian terdahulu guna mendukung peneltian ini, diantaranya, Pengembangan Multimedia pada Mata Siswaan Teknologi dan Komunikasi Kelas VIII. Hasil penelitian ini memaparkan bahwa multimedia pembelajaran interaktif yang dikembangkan layak digunakan oleh guru dan peserta didik pada mata pelajaran TIK kelas VIII dengan kategori kelayakan baik 
(Walusfa \& Kuswanto, 2017).

Penelitian lainnya mengenai pengembangan Multimedia Pembelajaran Bahasa Inggris Materi Functional Text bagi Peserta didik SMPN 3 Kalasan. Penelitian ini menunjukkan beberapa hasil, diantaranya menghasilkan produk multimedia dalam pembelajaran Bahasa Inggris dengan Functional Text menggunakan pendekatan komunikatif yang layak bagi peserta didik kelas VII SMP yang berbasis CD. Produk tersebut dinyatakan layak berdasarkan validasi guru, peserta didik, dan ahli materi. Produk ini efektif juga digunakan dengan pendekatan komunikatif pada pembelajaran materi Functional Text pada pembelajaran Bahasa Inggris di kelas VII SMPN 3 Kalasan (Niah \& Ismaniati, 2015).

Hasil penelitan lainnya dengan judul pengembangan multimedia pembelajaran Bahasa Inggris untuk SMK. Hasil penelitian ini mengemukakan bahwa media multimedia yang terdiri atas materi Bahasa Inggris dengan topik personality traits, people and compliments tergolong sebagai media yang sangat baik berdasar pada aspek materi dan pembelajaran. Ahli media juga menunjukkan bahwa media tersebut tergolong sangat baik. Pengunaan media tersebut juga mampu meningkatkan nilai ketuntasan peserta didik hingga $70 \%$ berbeda dengan pembelajaran dengan menggunakan buku cetak yang hanya mencapai 50\% (Surjono \& Susila, 2013).

Adapun penelitian yang akan dilakukan berikutnya bertujuan megembangkan multimedia pembelajaran yang disebut Wikitext yang layak digunakan dan mengetahui keefektifan penggunaan produk dalam pembelajaran teks deskriptif Bahasa Inggris di SMP. Penelitian pengembangan multimedia ini juga memiliki beberapa variabel yang berbeda dari penelitian-penelitian terdahulu. Perbedaannya adalah dari materi dan produk yang dikembangakan. Adapun materi yang diajarkan adalah Teks
Monolog Bahasa Inggris Teks Deskriptif di Tingkat SMP Sederajat yang dilakukan di kota Sorong. Sedang dari segi produk, produk pada penelitian sebelumnya menggunakan Macromedia Flash sebagai Software utama dalam dasainya sedangkan produk ini menggunakan $M y$ Autoplay Creator dan dalam pembuatan kuisnya menggunakan Quiz Creator. Multimedia dalam penelitian terdahulu berbasis $C D$ sedang dalam penelitian ini berbasis PC sehingga penginstalan softwarenya dapat dilakukan hanya dengan menggunakan flashdisk.

\section{B. TINJAUAN PUSTAKA \\ 1. Teknologi Pendidikan}

Teknologi pendidikan merupakan kegiatan yang mengolah teknologi menjadi sesuatu yang bisa digunakan dengan tepat dalam ranah pendidikan (Nurdyansyah, 2017). Melalui teknologi pendidikan pembelajaran dalam kelas seharusnya mampu didesain secara sistemik dan sistematik secara fisik ataupun maya tanpa batasan ruang dan waktu hinga pembelajaran bisa lebih menyenangkan sehingga materi yang diajarkan mudah difahami oleh peserta didik (Mukminan, 2012). Sedang menurut Suparman (2012), teknologi pendidikan ini merupakan studi dan parktik etis yang merupakan pemberian fasilitas belajar dengan mengaitkan kinerja dengan menghubungkan tiga domain yaitu penggunaan, penciptaan dan pengelolaan proses dan sumber daya teknologi secara tepat guna. Berdasarkan pendapat para ahli tersebut, telah disebutkan bahwa teknologi pendidikan merupakan salah satu cabang ilmu yang bertujuan untuk mencari solusi permasalahan pembelajaran di dunia pendidikan dengan pemnafaatan teknologi yang mengikuti perkembangan zaman.

Pendidikan sebagai sarana untuk mengembangkan potensi peserta didik, 
tentunya harus mampu bertransformasi sesuai dengan perkembangan zaman. Hingga tidak dapat dihindari lagi bahwa teknologi pendidikan harus senantiasa dihadirkan dalam setiap proses pembelajaran yang dilakukan di dalam kelas di zaman berteknologi ini. Hal tersebut tentu bertujuan menyesuaikan pembelajaran dengan keseharian peserta didik yang tak lepas dari teknologi.

Seiring dengan perkembangan teknologi, tentunya teknologi dalam pembelajaran ini selalu bergeser mulai dari hanya pemnafaatan alat teknologi, penggunaan teknologi perangkat lunak yang hanya berupa gambar, hingga saat ini tiba pada tahapan dimana teknologi yang berupa perangkat lunak mampu diciptakan untuk dimanfaatkan untuk pencapian tujuan pembelajaran atau bahkan untuk meningkatkan pemahaman peserta didik mengenai materi yang diajarkan. Oleh karena itu saat ini teknologi dalam pendidikan memiliki peran khusus yang tentunya sangat penting untuk dihadirkan dalam proses belajar mengajar di dalam kelas hal ini juga dikatakan oleh Nurdyansyah (2017) bahwa pergeseran teknologi yang terjadi selama bertahuntahun ini mejadikan teknologi berperan sangat penting dalam dunia Pendidikan.

Oleh karena itu salah satu fungsi utama teknologi yang mampu memudahkan segala urusan manusia tentunya diharapkan mampu menjadi media pembelajaran yang mampu memudahkan guru dan peserta didik mencapai tujuan pembelajaran.

\section{Pembelajaran dan Media Pembelajaran}

Pembelajaran merupakan dasar dari upaya pengembangan potensi diri manusia. Oleh karena itu pembelajaran merupakan proses dasar yang terusmenrus terjadi dalam kehidupan manusia seiring perkembangan yang terjadi di tiap individu.
Terdapat berbagai jenis teori pembelajaran menurut para ahli, yaitu: teori behavioristik Skinner, teori kognitif Jean Pieget, humanistik David Kolb dan teori pembelajaran kontemporer Jean Pieget dan Vygotsky. Kesemua aliran teori pembelajaran tersebut memiliki tujuan yang sama yaitu pengembangan kompetensi individu dengan pendekatan yang berbeda.

Perbedaan itu diantaranya, aliran Behavioristik dengan pembelajaran tingkah laku, Kognitif dengan meaningful learning, Humanistik dengan aktualisasi diri dengan memanusiakan manusia dan aliran Kontemporer dengan berdasar pada teori konstruktifisme dengan memandang pada bagaimana proses belajar itu terjadi.

Teori pembelajaran tersebut perlu menjadi bahan pertimbangan dalam menciptakan media pembelajaran. Karena media pembelajaran harus mampu mengakomodir seluruh kebutuhan pembelajaran peserta didik dalam proses belajar mengajar. Bahkan melalui media pembelajaran, ke-empat teori pembelajaran tersebut dapat digabungkan menjadi satu.

Ke-empat teori pembelajaran yang telah dikemukakan tersebut memiliki satu tujuan yang sama yaitu mengubah tingkah laku peserta didik minimal satu tingkah laku setelah dilakukan proses pembelajaran. Nah melalui media pembelajaran tujuan ini akan lebih mudah dicapai karena media pembelajaran merupakan media yang akan mengantarkan penerima lebih cepat menerima pesan yang akan disampaikan dari pada dengan tanpa menggunakan media. Oleh karena itu media dalam proses belajar mengajar sangat perlu selalu digunakan guna percepatan pencapaian tujuan pembelajaran.

\section{Media Pembelajaran}

Kata Media dalam Media Pembelajaran, berasal dari bahasa latin, dalam bentuk jamak dari "medium". Kata 
ini didefinisikan oleh Daryanto (2010) sebagai perantara atau pengantar terjadinya komunikasi dari pengirim terhadap penerima. Ketika mendefinisakan media secara umum, maka akan diperolah definisi yang sangat luas, tetapi jika dikerucutkan ke dalam definisi media dalam proses belajar mengajar maka akan diperoleh definisi berikut yaitu media yang digunakan sebagai bahan dan alat dalam kegiatan pengajaran dan pembelajaran guna mencapai tujuan pembelajaran.

Jenis media yang digunakan dalam proses belajar mengajar juga beragam. Menurut Daryanto (2010) terdapat 4 macam media pembelajaran yaitu: media teknologi cetak, audio visual, berbasis komputer dan media pembelajaran berbasis internet. Semua jenis media tersebut memiliki fungsi yang sama yaitu mengomunikasikan pesan yang ingin disampaiakan oleh guru ataupun sebalikanya dalam proses belajar mengajar.

Pemanfaatan media dalam proses belajar mengajar juga mampu mengefesiensikan waktu dalam proses pembelajaran. Pemberian instruksi yang dilakukan dengan bahasa verbal tentu akan menggunakan waktu yang lebih lama jika dibandingkan dengan pemanfaatan media pembelajaran untuk memberikan instruksi pembelajaran. Hal tersebut tentunya semakin menunjukkan betapa efisien pemanfaatan media pembelajaran yang menggunakan teknologi dalam proses belajar mengajar.

Melalui media pembelajaran, guru juga mampu merencakan penyampaian pesan dengan maksimal. Karena melalui berbagai jenis media yang ada mulai dari media proyeksi, media audio, media grafis, multimedia dan benda sekalipun harus mampu diorganisir dengan baik guna menampilkan materi atau pesan secara sederhana hingga mudah difahami oleh peserta didik. Melalui perencanaan yang baik, guru akan mampu membuat media pembelajaran yang mampu meningkatkan kejelasan pesan yang disampaikan kepada peserta didik.

\section{Multimedia Pembelajaran}

Seiring dengan perkembangan teknologi dan informasi, multimedia pembelajaran menjadi fokus tersendiri yang perlu dikembangkan dalam dunia pendidikan. Multimedia pembelajaran ini tentu mempermudah tugas guru dalam mencapai tujuan pembelajaran di kelas. Karena multimedia pembelajaran dapat digunakan sebagai media ajar yang menyenangkan serta menarik bagi peserta didik. Bahkan belajar dengen menggunakan multimedia dapat menjadikan jarak dan waktu tak lagi menjadi penghalang dalam proses belajar mengajar.

Secara terminologis multimedia merupakan perpaduan berbagai media (gambar, teks, animasi, video dan sebagainya) secara sinergis dan terpadu menggunakan peralatan elektronik (Komputer, Handphone, dll.) dengan tujuan tertentu (Surjono, 2017). Melalui gabungan berbagai jenis media ini, multimedia akan dengan mudah menarik perhatian peserta didik dalam proses pembelajaran hingga tujuan pembelajaran akan lebih mudah tercapai.

Multimedia dalam pembelajaran tentunya menggabungkan berbagai jenis media berupa teks, animasi, video dan lainlain menggunakan bantuan teknologi elektronik guna mencapai tujuan pembelajaran. Multimedia pembelajaran sangat sesuai dengan teori kognitif Mayer (2016) yang menyatakan bahwa ketika peserta didik belajar menggunakan multimedia pembelajaran maka peserta didik pasti mengalami beban kognitif. Beban kognitif ini berupa proses memilah informasi, membatasi informasi yang dapat diterima dan mengolah serta memadukan informasi terbaru yang diterima melalui multimedia pembelajaran. Oleh karena itu 
disain multimedia pembelajaran harus mampu mengakomodir ketiga prinsip tersebut guna memudahkan peserta didik memahami tujuan pembelajaran yang direncanakan.

Penggunaan multimedia dalam proses belajar mengajar juga diharapakan mampu mengakomodir perbedaan yang terdapat dalam pembelajaran karena multimedia bisa menyatukan beberapa unsur yang berbeda. Multimedia mampu mengombinasikan beberapa hal yaitu, teks, grafik, animasi, gambar, dan suara yang tentunya mampu memenuhi kebutuhan perbedaan kognitif yang ada dalam proses belajar mengajar.

\section{METODE PENELITIAN}

Pengembangan multimedia Wikitext ini termasuk dalam jenis penelitian Research and Development. Jenis pengembangan yang digunakan adalah model ADDIE (Analysis-Design-DevelopImplement- Evaluate) yang dikembangkan oleh Reiser dan Mollenda.

Secara umum tahapannya adalah sebagai berikut;

1. Analysis; menganalisis kebutuhan calon peserta didik mulai dari analisis karakteristik peserta didik, analisis kurikulum, dan analisis penggunaan multimedia dalam pembelajaran teks deskriptif Bahasa Inggris.
2. Design; mendesain menu utama dan menu quiz berdasar pada tahap analisis sebelumnya.

3. Develop; melakukan Pengembangan produk berdasar pada desain yang telah dibuat.

4. Implement; menguji coba produk dengan melalui validasi ahli materi dan multimedia sebelumnya.

5. Evaluate; setelah mengevaluasi produk secara formatif dalam tiap tahap pengembangannya, selanjutnya dilakukan evaluasi summatif untuk mengentahui keefektifan penggunaan produk.

Tahapan produk dapat dilihat pada Gambar 1.

Prosedur penelitian ini menggunakan tiga tahapan secara umum yaitu pra produksi, tahapan untuk mempersiapkan software yang dibutuhkan. Tahapan produksi, dalam tahapan ini, peneliti menggunakan prosedur pengembangan model ADDIE. Pasca produksi, pada tahapan ini dilakukan pengumpulan dokumen hasil review untuk melihat kemajuan proyek yang sedang dikembangkan, tentunya juga akan menjadi referensi untuk trouble shooting bila terjadi masalah, sebagai bahan pertimbangan dan sebagai pedoman operasional untuk pengembangan produk selanjutnya. Dalam tahapan ini pula, analisis data dilakukan guna memperoleh kesimpulan akhir penelitian.

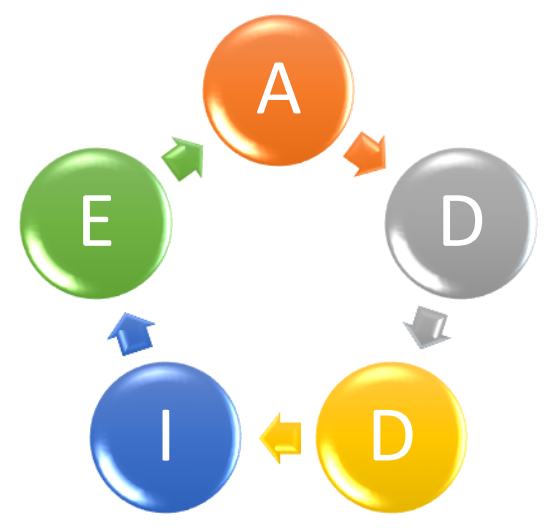

Gambar 1

Desain Model ADDIE (Analysis-Design-Develop-Implement-Evaluate) 


\section{HASIL DAN PEMBAHASAN}

\section{Pra Produksi}

Pada tahapan ini, peneliti mengumpulkan software yang dibutuhkan dalam pengembangan produk Wikitext. Daftar software yang telah dikumpulkan ditunjukkan pada table 1. Software tersebut adalah software yang digunakan dalam mendukung terciptanya produk Wikitext. Mulai dari software yang dibutuhkan untuk mengedit foto hingga software untuk mengkonversi file yang dibutuhkan hingga dapat dimasukkan kedalam software menu creator yang digunakan dalam membuat desain.

Tabel 1

Software yang dibutuhkan

\begin{tabular}{cll}
\hline No & Aplikasi & Fungsi \\
\hline 1. & My Autoplay Creator & Membuat Menu \\
\hline 2. & Quiz Creator & $\begin{array}{l}\text { Membuat excersice listening, } \\
\text { speaking, reading, dan writing. }\end{array}$ \\
\hline 3. & Xilisoft Video Converter & Mengedit rekaman suara \\
\hline 4. & PPT to PDF Converter & Mengkonversi PPT ke SWF \\
\hline 5. & Keyboard Print Screen & Merekam tampilan desktop \\
\hline 7. & PhotoScape & Mengedit foto \\
\hline Sumber : Rekontruksi Peneliti, 2019 &
\end{tabular}

\section{Produksi}

Tahapan produksi produk Wikitext dilakukan melalui prosedur ADDIE berikut:

\section{a. Tahap I : Analisis (Analysis)}

Di tahapan ini, peneliti menganalisis proses pembelajaran yang berlangsung di sekolah, khususnya SMPN/MTs sederajat dengan melakukan identifikasi media pembelajaran yang dibutuhkan agar bisa disimpulkan kebutuhan multimedia Wikitext secara pasti. Analisis kurikulum, analisis kemampuan Bahasa Inggris peserta didik dan Analisis penggunaan LCD proyektor dan lab komputer telah dilakukan. Berikut hasil analisis yang telah dilakukan:

1) Analisis Kurikulum

Analisis kurikulum dilakukan melalui wawancara Bersama guru Bahasa Inggris yang mengajar di SMP Islam GUPPI Kota Sorong melalui telepon. Hasil Wawacara menunjukkan bahwa SMP Islam GUPPI Mempelajari teks desktiptif di kelas VIII dan belum menggunakan Multimedia sebagai media pembelajaran. Beliau menyampaikan bahwa pembelajaran teks deskriptif masih diajarkan dengan menggunakan buku teks dan belum menggunakan multimedia bahkan proyektor.

2) Analisis Peserta didik

Untuk mengetahui kemampuan peserta didik, wawancara dengan guru mata pelajaran Bahasa Inggris telah dilakukan. Guru Bahasa Inggris mengatakan kurang lebih $70 \%$ peserta didik kelas VIII tahun akademik 2018 / 2019 SMP Islam Guppi Kota Sorong memiliki Kemampuan Bahasa Inggris pada level Menengah ke bawah. Menurutnya dari 29 peserta didik, hanya 8 peserta didik yang memiliki kemampuan Bahasa Inggris yang tergolong baik.

3) Analisis Pemanfaatan Proyektor dan Lab Komputer.

Berdasar pada hasil wawancara dengan guru mata pelajaran Bahasa Inggris, pemanfaatan LCD proyektor dalam pembelajaran Bahasa Inggris masih jarang dilakukan. Lab computer juga belum tersedia di SMP Islam GUPPI.

Multimedia pembelajaran Wikitext ini selain bisa diajarkan menggunakan 
proyektor karena menggunakan audio, visual, animasi, dan gambar, pembelajaran menggunakan multimedia Wikitext ini juga bisa dilakukan secara mandiri oleh peserta didik saat berada di mana saja melalui PC atau laptop. Multimedia ini telah disesuaikan dengan pembelajaran menggunakan proyektor atau Komputer.

\section{b. Tahap II : Desain (Design)}

Pada tahapan ini, peneliti mendesain menu utama, desain quiz dan mendesain tampilan pada multimedia.

1) Desain Menu Utama

Menu utama di desain dengan mempertimbangkan point-point utama yang harus dipelajari dalam teks monolog. Seperti; Definition, Language Feature, Generic Structure, Example, Quiz dan Exit yang bisa dipilih sesuai keinginan.

Setiap membuka pilihan pada menu utama, peserta didik akan disuguhkan pemaparan lengkap materi yang berkaitan dengan pilihan peserta didik dengan cara yang sederhana. Bahkan jika memungkinkan peserta didik bisa memerintakan multimedia ini untuk mencetak materi dengan mengklik tombol printer yang telah disediakan. Peserta didik juga bisa mengulang materi pembelajaran sesuai keinginan. Hal tersebut tentu akan memudahkan peserta didik untuk mengontrol proses pembelajarannya sendiri tanpa harus meminta guru mengulanginya.

\section{2) Desain Quiz}

Latihan dalam Multimedia Wikitext didisain secara interaktif dan bisa diulang hingga peserta didik memperoleh nilai sempurna untuk masing-masing quiz. Terdapat berbagai jenis quiz yang disedikan yaitu; E- ListComp, EReadComp, E-Words, E-Response, EClick, dan E-Sequence. Semua Jenis quiz tersebut mewakili tujuan pembelajaran yang berbeda-beda.

E-ListComp dan E-ReadComp bertujuan melatih pemahaman peserta didik mengenai deskripsi dalam bentuk teks dam dalam percakapan. E-Words bertujuan mengecek pemahaman peserta didik mengenai Generic Structure dari sebuah teks deskriptif. E-Response melatih pemahaman peserta didik mengenai deskripsi gambar yang ditunjukkan. Sedang kuis E-Sequence bermanfaat untuk melatih kemampuan peserta didik dalam menulis teks deskriptif dengan menyusun susunan kalimat acak yang telah disediakan. Desain menu utama dapat dilihat pada Gambar 2 dan desain sub menu ditunjukkan pada Gambar 3.

Semua jenis quiz memberikan kesempatan kepada peserta didik untuk belajar sambil bermain. Selain fasilitas pengulangan pengerjaan kuis, peserta didik juga bisa memilih nomor yang ingin dikerjakan dengan mengklik tombol outline yang tersedia pada layar. Peserta didik dapat berhenti sejenak dalam pengerjaan kuis dan dapat dilanjutkan kembali di lain waktu jika diinginkan.

Tentunya disediakan tombol yang dibutuhkan untuk kembali ke kuis dan atau kembali ke menu utama. Bahkan tombol minimize disediakan ketika peserta didik ingin berhenti sejenak dalam pembelajaran. Seluruh rencana desain tersebut akan diaplikasikan ke menu dalam tahapan pengembangan berikutnya. 


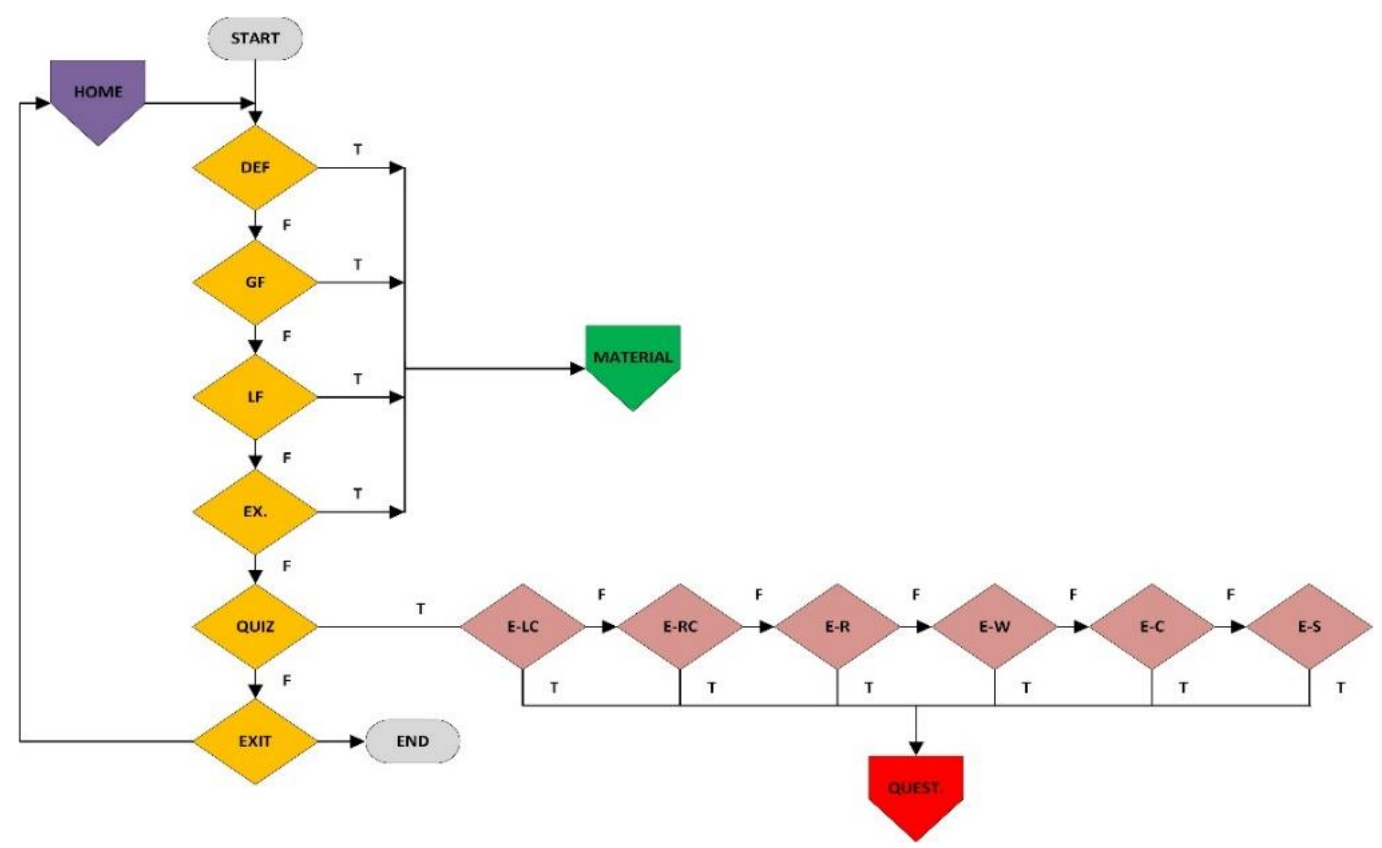

\section{Gambar 2}

Desain Menu Utama
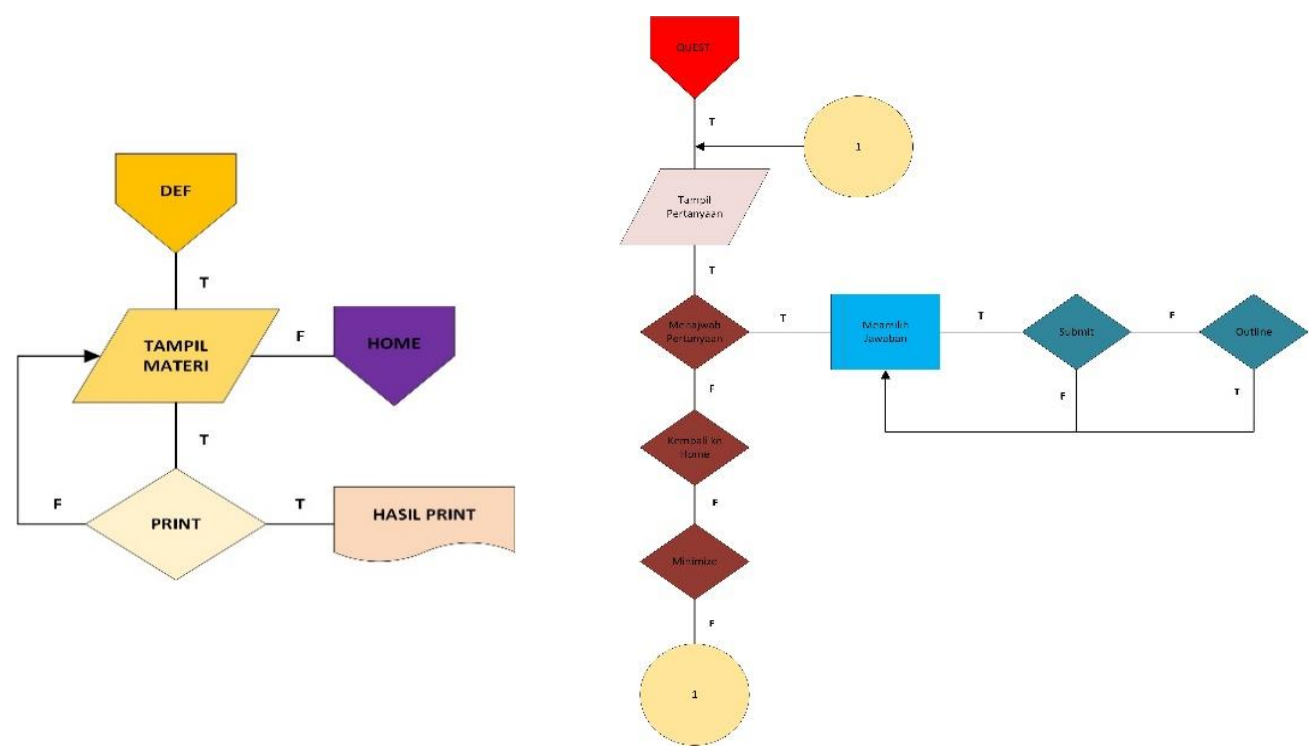

Gambar 3

Desain Sub Menu

\section{c. Tahap III: Pengembangan}

\section{(Develop)}

1) Pembuatan Menu Utama

Pengembangan Menu Utama pada produk ini dilakukan dengan mengikuti flowchart desain yang telah direncanakan pada Gambar 2 dan 3. Perancangan aktivitas yang interaktif diaplikasikan pada produk di tahapan ini. Desian menu utama disesuaikan dengan sasaran peserta didik yang akan belajar menggunakan produk Wikitext ini. Pemilihan warna dan huruf juga disesuikan guna memberikan hasil terbaik. Adapun hasil pengembangan 
menu utama dapat dilihat pada Gambar 4.

Sangat diharapkan produk ini dapat digunakan sebagai media pembelajaran para guru Bahasa Inggris. Produk ini juga bisa menjadi ringkasan yang berisi latihan yang bisa digunakan oleh peserta didik secara mandiri kapan dan dimanapun peserta didik berada.

2) Pembuatan Halaman

Halaman dibuat Berdasarkan sub menu yang telah disiapkan pada halaman utama. Terdapat empat sub menu yang sama, yaitu sub menu yang berisi materi (Definition, Generic structure, dan Language Feature) dan contoh teks deskriptif. Satu sub menu yang berisi contoh teks deskriptif. Satu sub menu untuk mengerjakan berbagai jenis kuis yang disediakan guna mencapai tujuan pembelajaran. Satu sisanya merupakan sub menu yang berfungsi untuk mengakhiri produk. Jadi jumlah sub menu yang disediakan untuk halaman lainnya adalah 6 sub menu dengan fungsinya masingmasing. Adapun pengembangan Sub menu ditunjukkan pada Gambar 5.

3) Input Materi

Setelah semua sub menu melalui halaman baru disusun, tahapan selanjutnya adalah memasukkan materi dan tombol-tombol interaktif yang dibutuhkan.

Materi yang dimasukkan berupa power point yang dikonversi menjadi PDF agar compatible dengan pembuat menu yang digunakan. Sedang tombol interaktif didisain sedemikian rupa agar bisa forward atau backward untuk memudahkan peserta didik berinteraksi dengan multimedia Wikitext.

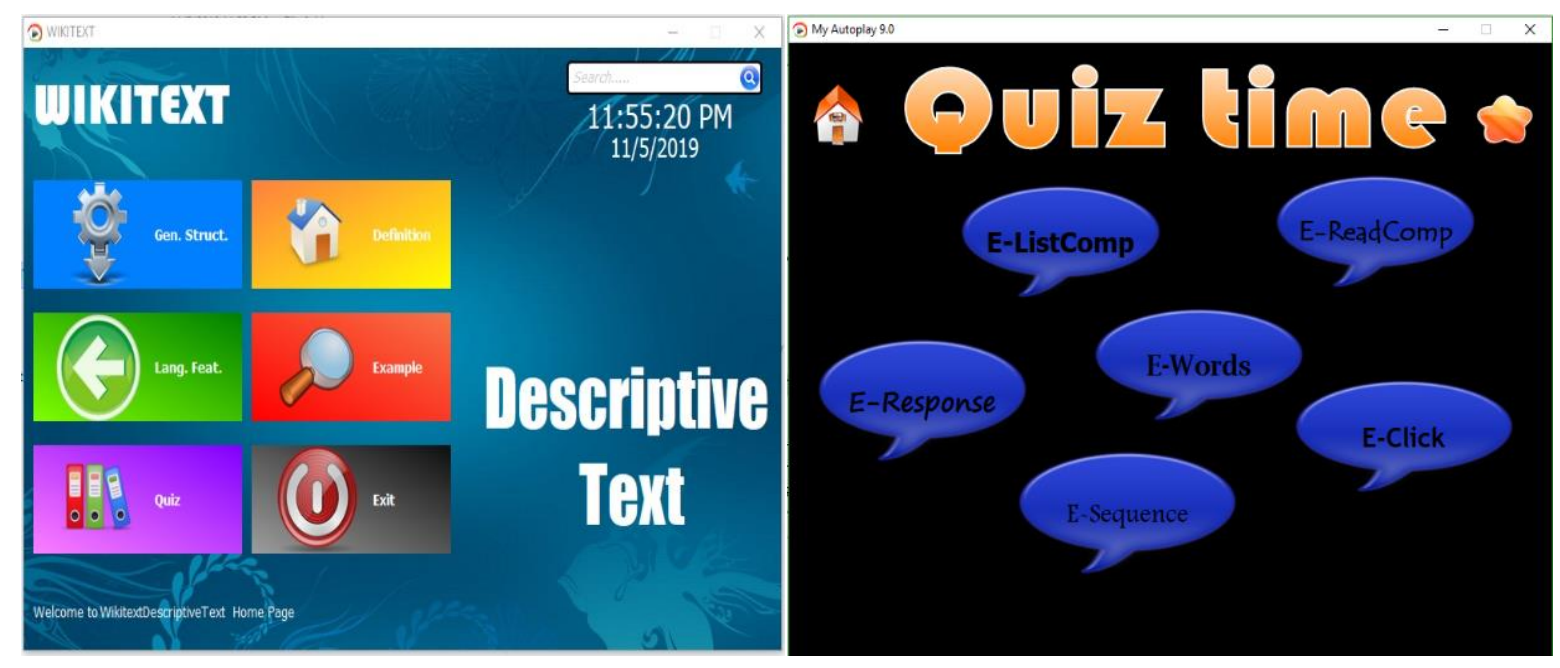

Gambar 4

Pengembangan Menu Utama 


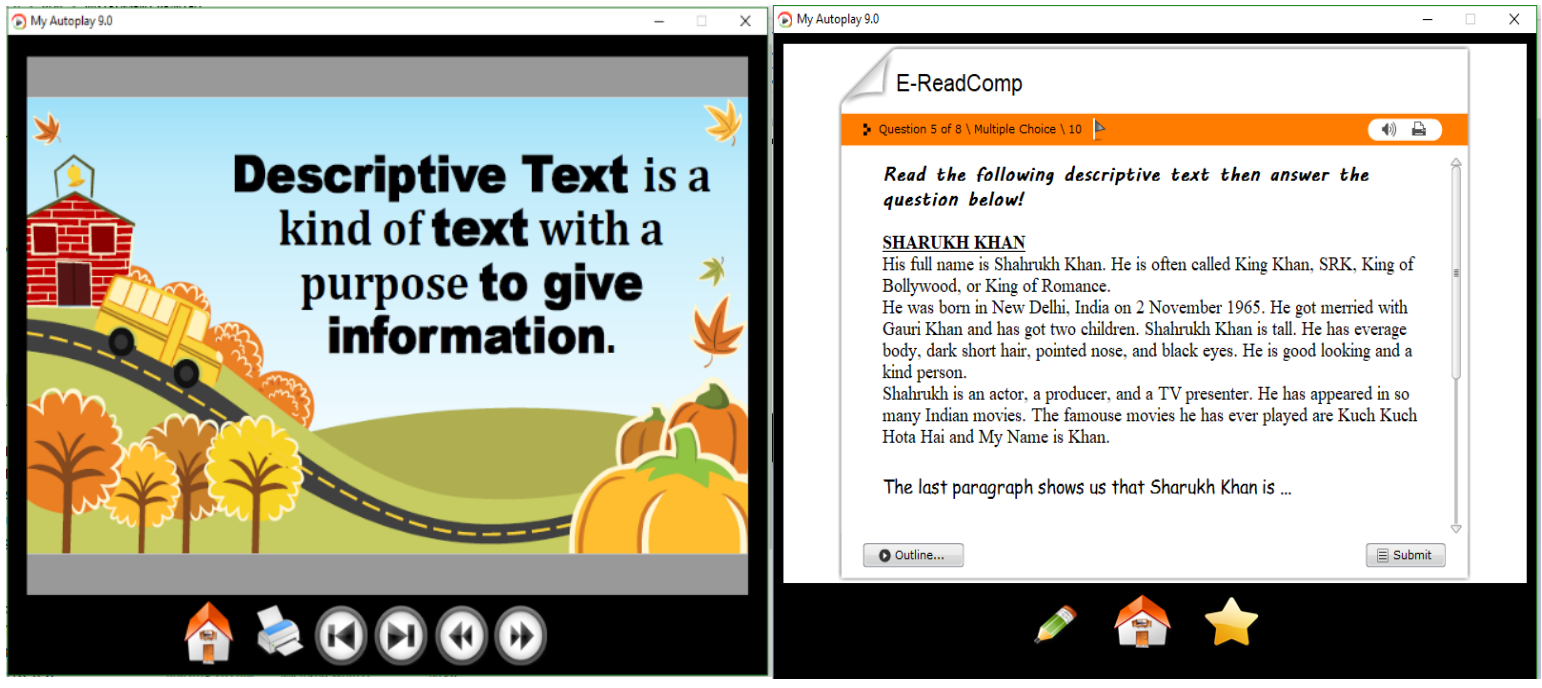

Gambar 5

Pengembangan Sub Menu

4) Hasil Validasi Ahli

Untuk mengetahui kelayakan penggunaan produk multimedia Wikitext dalam pembelajaran teks deskriptif, validasi ahli materi dan ahli multimedia telah dilakukan melalui angket.

Angket validasi ahli materi diberikan kepada guru mata pelajaran Bahasa Inggris yang berpengalaman dan angket validasi ahli multimedia diberikan kepada ahli di bidang multimedia. Berdasarkan hasil analisis ini juga akan memungkinkan dilakukan revisi Pengembangan jika diperlukan.

Hasil analisis angket menunjukkan rata-rata 3.85 yang berada pada kategori sangat valid. Sehingga Multimedia Wikitext dalam pembelajatan teks deskriptif ini layak diuji cobakan. Data tersebut ditunjukkan pada Table 2 .

Tabel 2

Hasil Validasi Multimedia dan Materi dalam

Pembelajaran Teks Deskriptif Bahasa Inggris

\begin{tabular}{|lccc|}
\hline \multicolumn{1}{|c}{ Sumber } & $\begin{array}{c}\text { Skor } \\
\text { Rata-rata }\end{array}$ & Kriteria \\
\hline $\begin{array}{l}\text { Multimedia "Wikitext" } \\
\text { pembelajaran teks monolog Descriptive }\end{array}$ & 3.8 & Sangat Valid \\
$\begin{array}{l}\text { Text untuk SMP. } \\
\text { Materi Multimedia "Wikitext" dalam }\end{array}$ & 3.9 & Sangat Valid \\
$\begin{array}{l}\text { pembelajaran teks monolog Descriptive } \\
\text { Text untuk SMP. }\end{array}$ & & \\
\hline Rata-rata keseluruhan Multimedia & 3.85 & Sangat Valid \\
\hline
\end{tabular}

Sumber : Rekontruksi Peneliti, 2019

\section{b. Tahap IV : Implementation (Uji Coba Produk)}

Setelah melalui uji coba produk Wikitext dan Validasi Ahli, yaitu ahli materi dan multimedia, selanjutnya dilakukan uji coba penggunaan multimedia wikitext dalam pembelajaran teks deskriptif di 
dalam kelas VIII di SMP Islam GUPPI Kota Sorong.

Sebelum uji coba dilakukan, Peserta didik diberi pre-test untuk mengetahui kemampuan peserta didik mengenai teks deskriptif sebelum pengaplikasian produk. Setelah pelaksanaan pembelajaran selanjutanya diberikan post-test guna mengetahui efektifitas pembelajaran teks deskriptif menggunakan multimedia Wikitext ini.
Pembelajaran dalam uji coba di SMP Islam GUPPI menggunakan LCD Proyektor. Sejumlah 29 peserta didik kelas VIII di SMP Islam Guppi Kota Sorong yang berpartsipasi dalam uji coba produk ini. Proses implementasi produk ditunjukkan pada Gambar 6. Adapun hasil uji coba berdasar pada evaluasi summatif dan hasil respon pesera didik dipaparkan pada tahapan selanjutnya.

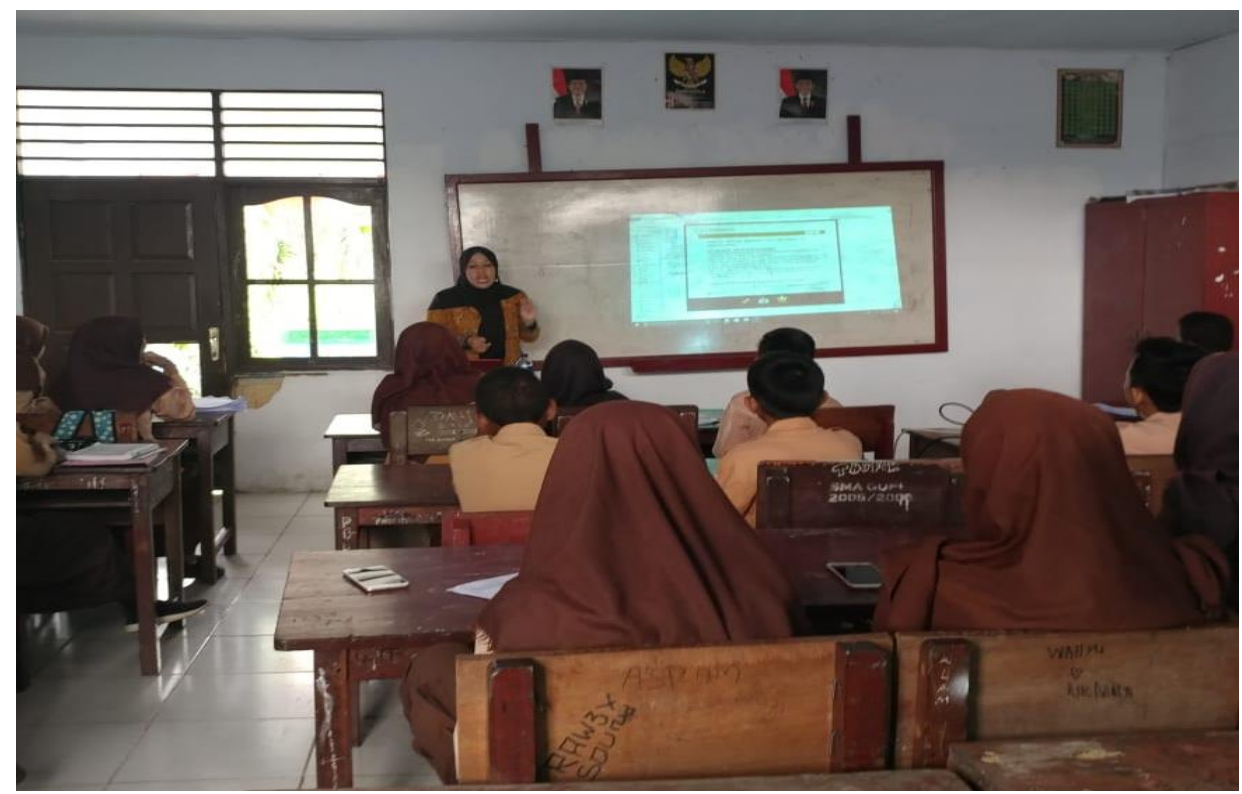

Gambar 6

Implementasi Produk

\section{b. Tahap V : Evaluation (Evaluasi)}

Tahapan evaluasi formatif melalui validadi ahli media dan materi telah dilakukan untuk mengetahui kelayakan produk dari sisi kelayakan multimedia dan kelayakan materi yang akan diajarkan sebelum uji coba. Hasil validasi ahli multimedia dengan menilai aspek format multimedia; kesesuaian jenis dan ukuran huruf serta pengaturan tata letak gambar dan teks; kesesuaian gambar; ilustrasi; tampilan; keseimbangan teks dan ilustrasi, aspek bahasa; bahasa yang digunakan; kejelasan bahasa yang digunakan hingga pemilihan struktur dan kata yang digunakan; dan aspek isi; kesesuaian isi dengan siswa target dan dengan materi yang ditampilkan; dan keterkaitan antara materi dengan multimedia. Adapun penilaian selanjutnya yaitu dari ahli materi. Ahli materi menilai dari aspek berikut; kejelasan materi; relevansinya dengan SK/KD dan kurikulum; kesesuaian materi dengan tujuan pembelajaran; kontextualitas, aktualitas; kelengkapan dan kedalaman materi; kemudahan pemahaman; sistematika; dan kejelasan quiz. Hasil penialian tersebut menunjukkan bahwa multimedia ini layak digunakan dalam pembelajaran teks deksriptif dari sisi multimedia dan materi. Hasil penilaian dapat dilihat pada table 2 . 
Setelah melalui evaluasi fromatif, selanjutnya evaluasi summative dilakukan untuk mengetahui kefektifan produk dalam mencapai tujuan pembelajaran yang telah direncanakan. Peneliti melakukan evaluasi summatif dengan menganalisis data tes hasil belajar peserta didik. Analisis ini berdasar pada hasil tes yang telah diselesaikan oleh seluruh peserta didik kelas VIII dalam pre-test dan posttest. Data hasil test ditunjukkan pada Gambar 7.

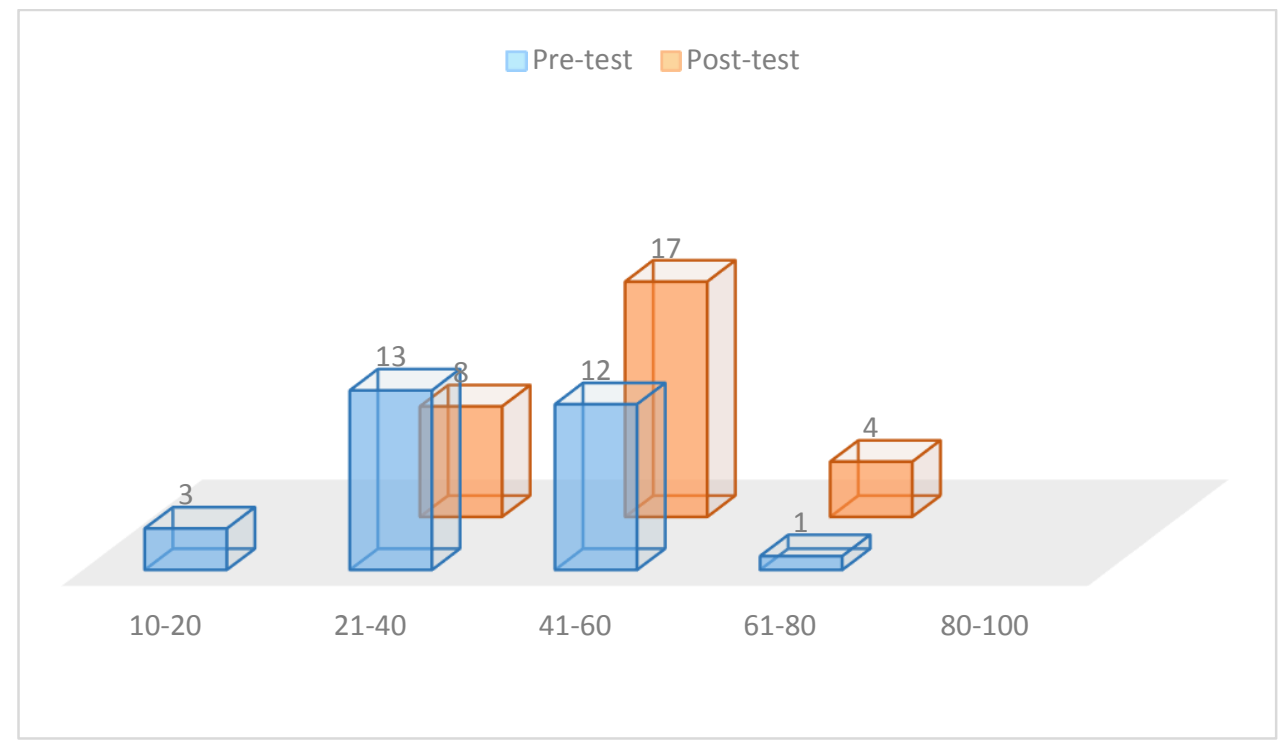

Gambar 7

Bagan Hasil Pre-test dan Post-test

Pemberian pre-test dan post-test dilakukan saat uji coba prod uk dalam pembelajaran teks deskriptif di dalam kelas. Ukuran kefektifan uji coba produk multimedia Wikitext adalah minimal terdapat peningkatan $30 \%$ peserta didik yang memperoleh Nilai 60 pada hasil posttest jika dibandingkan dengan pre-test.

Uji Coba yang dilakukan di SMP Islam GUPPI Kota Sorong menunjukkan hasil Pre-tes yaitu 10\% peserta didik memeproleh Nilai 60 dan pada post-test terjadi peningkatan sebesar 34\% yaitu meningkat dari $10 \%$ menjadi $44 \%$ atau dari 3 peserta didik menjadi 13 Peserta didik yang memeproleh Nilai 60 pada hasil posttest.

Setelah implementasi produk dilakukan dalam pembelajaran, peserta didik diberi angket untuk mengetahui respon peserta didik mengenai produk yang digunakan dalam pembelajaran teks deskripttif. Sejumlah 29 peserta didik telah mengisi engket tentang penggunaan produk Wikitext dalam pembelajaran yang menunjukkan hasil rata-rata $93.6 \%$ dengan respon yang sangat positif. Angket tersebut berisi pendapat peserta didik mengenai penggunaan produk dalam implementasi pembelajaran yang peserta didik alami. Diantaranya; tampilan multimedia, kejelasan materi, ilustrasi, tulisan dan suasana belajar, serta ketertarikan dan motivasi belajar yang dirasakan saat mengalami pembelajaran menggunakan produk yang dikembangkan.

Bedasarkan hasil pelaksanaan ADDIE tersebut di atas, hasil validasi ahli materi dan ahli multimedia dengan rerata 3.85 dalam kategori sangat valid menunjukkan bahwa Multimedia Wikitext 
ini layak diaplikasikan dalam peroses belajar mengajar teks deskriptif Bahasa Inggris di SMP.

Adapun keefektifan penggunaan produk juga telah ditunjukkan oleh peningkatan minimal $30 \%$ jumlah peserta didik yang memperoleh nilai 60 pada hasil Pos-tes yaitu dari $10 \%$ peserta didik menjadi $44 \%$ peserta didik dalam satu kali uji coba pengaplikasian produk dalam pembelajaran teks deskriptif. Hasil penelitian yang sama juga ditemukan oleh Suartama (2010), Riana (2015) dan Jumasa (2016).

\section{Pasca Produksi}

Tahapan pasca produksi dilakukan dengan mengumpulkan semua dokumen hasil review dari angket ahli materi, ahli multimedia dan hasil angket respon peserta didik sebagai referensi untuk pengembangan produk selanjutnya. Pada tahapan ini, dilakukan analisis data untuk kesimpulan pengembangan produk yang telah dilakukan.

\section{E. KESIMPULAN}

Multimedia Wikitext yang telah dikembangkan, mampu meningkatkan hasil pembelajaran dengan satu kali uji coba. Hal tersebut menunjukkan bahwa pemanfaatan multimedia Wikitext dalam pembelajaran sangat beramanfaat untuk dilakukan dalam pembelajaran teks monolog Bahasa Inggris khususnya pada materi teks deskriptif.

Multimedia Wikitext yang dikembangkan mendukung pembelajaran mandiri bagi peserta didik. Peserta didik dapat memindahkan multimedia Wikitext ini untuk disimpan dalam PC atau laptop sehingga materi teks deskriptif dapat dipelajari kapan dan di mana saja tanpa didampingi guru.

Desain yang menarik dengan berbagai jenis quiz sederhana akan mampu mengakomodir keberagaman cara belajar peserta didik ketika belajar secara mandiri.

\section{DAFTAR PUSTAKA}

Daryanto. (2010). Media Pembelajaran (Peranannya Sngat Penting Dalam Mencapai Tujuan Pembelajaran). Yogyakarta: Gaya Media.

Jumasa, M. A., \& Surjono, H. D. (2016). Pengembangan Multimedia Pembelajaran Bahasa Inggris Untuk Pembelajaran Teks Recount Di Mtsn li Yogyakarta. Jurnal Inovasi Teknologi Pendidikan, 3(1), 25-39.

Mukminan. (2012). Teknologi Pendidikan untuk Peningkatan Kualitas Pembelajaran. Teknologi Pendidikan Untuk Peningkatan Kualitas Pembelajaran, 1-14.

Niah, S., \& Ismaniati, C. (2015). Developing English Learning Multimedia For The Topic Of Functional Text Students Of Smpn 3 Kalasan. Jurnal Inovasi Dan Teknologi Pendidikan, 2(2), 121-131.

Nurdyansyah, N. (2017). Sumber Daya dalam Teknologi Pendidikan. Universitas Negeri Surabaya.

R. C. Clark \& R. E. Mayer. (2016). E-Learning and The Science of Instruction: Proven Guidelines for Consumers and Designers of Multimedia Learning. America: John Wiley \& Sons.

Riana, E., \& Gafur, A. (2015). Pengembangan Multimedia Interaktif Pembelajaran Bahasa Inggris Materi Teks Deskriptif Untuk Siswa SMP/MTs. Jurnal Inovasi Teknologi Pendidikan, 2(2), 212-224.

Suartama, I. K. (2010). Pengembangan Mutimedia untuk Meningkatkan Kualitas Pembelajaran pada Mata Kuliah Media Pembelajaran. Jurnal Pendidikan Dan 
Pengajaran, 43(3), 253-262.

Supardi, A. (2014). Penggunaan Multimedia Interaktif Sebagai Bahan Ajar Suplemen Dalam Peningkatan Minat Belajar. Jurnal IImiah Pendidikan Dasar, 1(2), 161-167.

Suparman, M. A. (2012). Desain Instruksional Modern. Jakarta: Erlangga

Surjono, H. D. (2017). Multimedia Pembelajaran Interaktif Konsep dan Pengembangan. Yogyakarta: UNY Press

Surjono, H. D., \& Susila, H. R. (2013). Pengembangan multimedia pembelajaran bahasa inggris untuk SMK. Jurnal Pendidikan Vokasi, 3(1), 45-52.

Walusfa, Y., \& Kuswanto, J. (2017). Pengembangan Multimedia Pembelajaran pada Mata Pelajaran Teknologi Informasi dan Komunikasi Kelas VIII. Jurnal Pendidkan Dan Teknologi Informasi, 6(2), 58-64. 